\title{
Glucagon-Induced Increase in Plasma Potassium Levels in Type 1 (Insulin-Dependent) Diabetic Subjects
}

\author{
E. Cagliero, V. Martina, F. Massara and G. M. Molinatti \\ Department of Endocrinology, University of Turin, Turin, Italy
}

\begin{abstract}
Summary. To investigate the hypothesis that in Type 1 (insulin-dependent) diabetes the increase in plasma potassium during decompensation may be due to a rise in glucagon concentrations, we have measured plasma glucose, potassium and glucagon levels in five diabetic patients during two tests with $0.154 \mathrm{~mol} / \mathrm{l}$ saline or somatostatin $(500 \mu \mathrm{g} / \mathrm{h})$ performed on two successive days. The patients were maintained normoglycaemic overnight by means of a continuous insulin infusion. After insulin withdrawal during the saline infusion, glucose and potassium levels rose markedly ( $\Delta$ maximum: glucose, $12.0 \pm 1.5 \mathrm{mmol} / 1$; potassium, $0.73 \pm 0.12 \mathrm{mmol} / \mathrm{l}$ ), while
\end{abstract}

glucagon showed a slight, but significant increment $(\Delta$ maximum: $10.6 \pm 1.0 \mathrm{pmol} / \mathrm{ml}, p<0.05$ ). The potassium increment was not mediated by a reduction in blood $\mathrm{pH}$. Somatostatin abolished the rise in glucagon concentration and simultaneously markedly inhibited the rise in potassium and glucose levels. It is concluded that in acute insulin deficiency, glucagon could be one of the factors that contributes to hyperkalaemia.

Key-words: Type I diabetes, glucagon, potassium, hyperkalaemia.
We have previously shown that the hyperkalaemic effect of glucagon is unmasked in normal subjects following the suppression of basal insulin secretion by somatostatin [1]. Now, we have investigated the possibility that in Type 1 diabetes the glucagon increase during a period of metabolic decompensation may be responsible for an increase in plasma potassium.

\section{Patients and Methods}

Eight Type 1 diabetic patients (three males and five females, aged 17-33 years) were studied. During the 2 days before the study, the patients were maintained on multiple doses of soluble insulin before meals. After dinner $(20.00 \mathrm{~h})$ on the evening before the tests, 15 units were infused as an IV bolus followed by a constant infusion for approximately $12 \mathrm{~h}$ of $0.154 \mathrm{~mol} / \mathrm{l}$ saline containing insulin, by means of a Braun infusion pump (Melsungen, FRG). Normoglycaemia was maintained in all subjects by an average infusion rate of $1.25 \mathrm{U} / \mathrm{h}$. At $0.800 \mathrm{~h}$ the insulin was stopped and patients fasted until $14.00 \mathrm{~h}$. Venous blood samples for the determination of plasma glucose, glucagon, C-peptide and potassium levels were withdrawn every $30 \mathrm{~min}$. Capillary blood for $\mathrm{pH}$ determination (in three patients only) was collected every $60 \mathrm{~min}$ by means of a heparinized glass capillary tube from the finger-tip following $5 \mathrm{~min}$ immersion of the hand in warm water.

Five of the eight patients underwent a second experiment the following day. The same protocol was followed except that from $0.800 \mathrm{~h}$ to $13.00 \mathrm{~h}$ cyclic somatostatin $(500 \mu \mathrm{g} / \mathrm{h})$ instead of saline was infused.
Plasma potassium and glucose levels were measured by the methods described previously [1]. Plasma glucagon was measured by a single antibody radioimmunoassay (antibody RC S5 kindly supplied by Dr. S.R. Bloom, Hammersmith Hospital, London, UK; charcoal dextran was used to separate the free hormone). The detection limit of the method in our laboratory is $4.5 \mathrm{pmol} / \mathrm{ml}$. C-peptide was measured by a single antibody radioimmunoassay kit (Behring Institute, Frankfurt, FRG); the detection limit of the method is $0.3 \mathrm{ng} / \mathrm{ml}$. Blood $\mathrm{pH}$ was determined with a Radiometer (Copenhagen, Model BMS3, MK2: blood microsystem).

Student's paired t-test was used for statistical analysis.

\section{Results}

The data for glucose, potassium and glucagon levels during the two tests are shown in Figures 1 and 2.

At time 0 (insulin withdrawal) during the two tests, the levels of plasma glucagon, glucose and potassium were similar and in the normal range. In the first test, plasma glucose, glucagon and potassium levels began to rise after time 0 . Glucose levels reached a plateau (median $16.5 \mathrm{mmol} / \mathrm{l}$ ) at $180 \mathrm{~min}$. Glucagon levels increased modestly but significantly from a basal value of $11.7 \pm 1.6 \mathrm{pmol} / \mathrm{ml}$ to a mean plateau level of $19.8 \mathrm{pmol} / \mathrm{ml}$ at $210 \mathrm{~min}$ ( $p<0.05$, Fig. 1). Potassium (basal value: $3.6 \pm 0.16 \mathrm{mmol} / 1)$ peaked at $180-240 \mathrm{~min}(\Delta$ maximum $=0.73 \pm 0.12 \mathrm{mmol} / 1 ; p<$ 
0.001, Fig. 2). C-peptide (not shown) was undetectable in all the samples.

There was no correlation between potassium increases and the corresponding levels of plasma glucose or glucagon ( $r=0.02, r=0.03$, respectively).

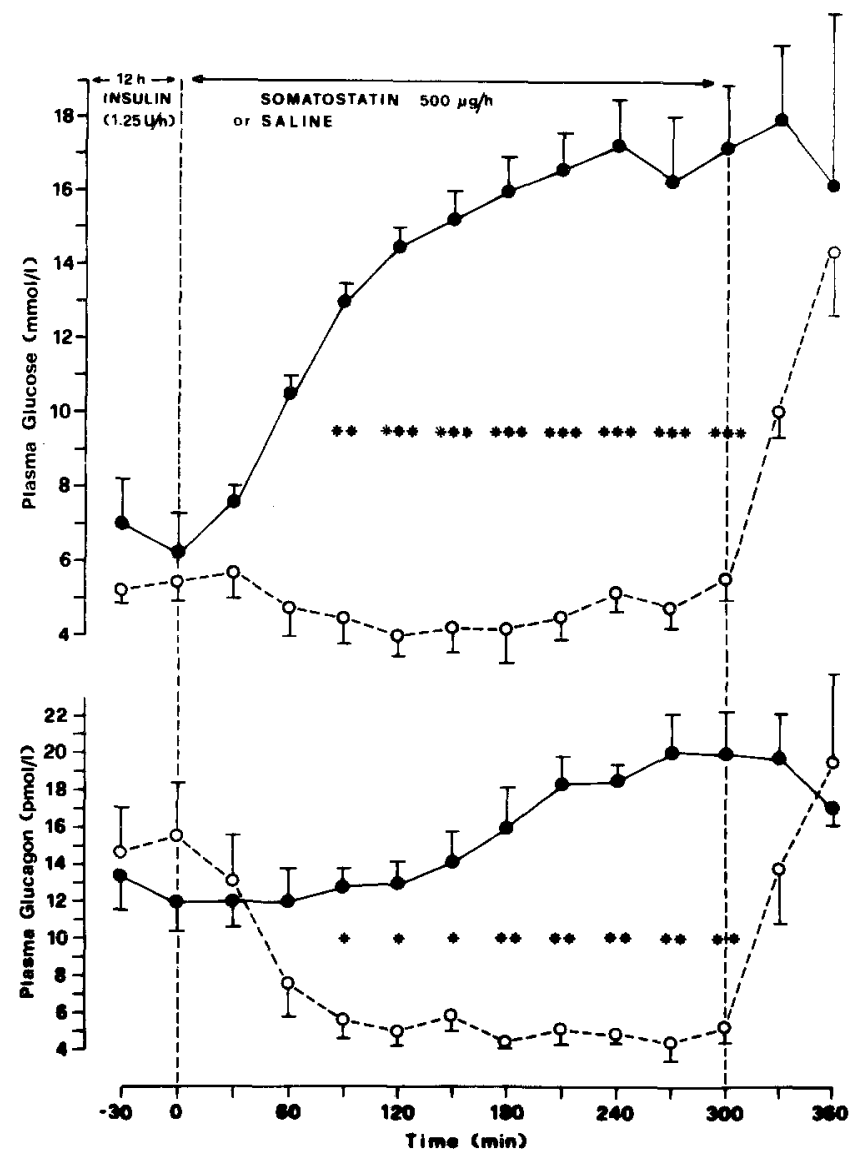

Fig. 1. Effect of somatostatin $(500 \mu \mathrm{g} / \mathrm{h}) \quad 0 \ldots$ and $0.154 \mathrm{~mol} / \mathrm{s}$ saline on plasma glucose and glucagon levels after acute withdrawal of insulin in five patients with Type 1 diabetes. $p<0.05 ; p<$ $0.02 ; p<0.01$ between the two tests
In the test with somatostatin, glucagon fell by at least $60 \%$, and remained suppressed at $4.5-8.1 \mathrm{pmol} / \mathrm{ml}$ until the end of the infusion, after which there was a rapid return to basal values. Glucose, after an initial modest fall, maintained a normal steady level until the end of the infusion, then it rapidly increased to hyperglycaemic levels (9.4-13.0 mmol/1, Fig.1). Plasma potassium (basal value: $3.77 \pm 0.05 \mathrm{mmol} / \mathrm{l}$ ) rose much less than in the control study $(\Delta$ maximum $=0.35 \pm$ $0.07 \mathrm{mmol} / 1 ; p<0.01$ versus $\Delta$ maximum during the control test).

To investigate the possible role of acidosis in the potassium increase, we submitted three patients to the control test alone. As seen in Table 1, the rise in potassium preceded the late fall in $\mathrm{pH}$.

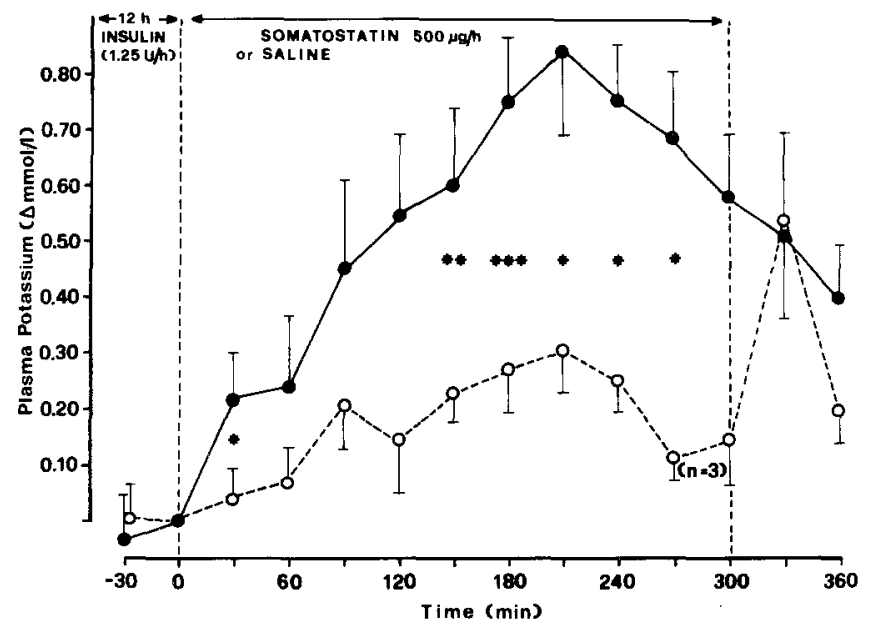

Fig. 2. Effect of somatostatin $(500 \mu \mathrm{g} / \mathrm{h}) \mathrm{O}_{--} \mathrm{O}$ and $0.154 \mathrm{~mol} / 1 \mathrm{sa}-$ line on plasma potassium increment (expressed as change with respect to 0 time values) after acute withdrawal of insulin in five patients with Type 1 diabetes. Time $270 \mathrm{~min}$ of somatostatin test refers to only three patients. $p<0.05 ; p<0.02 ; p<0.01$ between the two tests

Table 1. Plasma glucose and potassium levels and blood $\mathrm{pH}$ in three Type 1 diabetic subjects after withdrawal of insulin infusion (at time 0 )

\begin{tabular}{llllllllllllll} 
Time (min) \\
\hline 30 & 0 & 30 & 60 & 90 & 120 & 150 & 180 & 210 & 240 & 270 & 300 & 330 & 360
\end{tabular}

\section{Patient 1}

Plasma glucose $(\mathrm{mmol} / 1)$

Plasma potassium (mmol/1)

Blood pH

Patient 2

Plasma glucose $(\mathrm{mmol} / \mathrm{l})$

Plasma potassium (mmol/1)

Blood pH

Patient 3

Plasma glucose $(\mathrm{mmol} / \mathrm{l})$

Plasma potassium (mmol/l)

Blood pH

$\begin{array}{llcccccccccccc}6.6 & 6.0 & 9.5 & 11.1 & 10.7 & 12.4 & 12.8 & 13.0 & 12.9 & 13.4 & 12.5 & 13.0 & 13.2 & 12.7 \\ 4.3 & 4.2 & 4.4 & 4.5 & 4.4 & 4.6 & 4.6 & 4.8 & 4.8 & 4.7 & 4.7 & 4.8 & 4.6 & 4.6 \\ 7.41 & 7.40 & - & 7.44 & - & 7.45 & - & 7.40 & - & 7.40 & - & 7.30 & - & 7.27 \\ & & & & & & & & & & & & & \\ 4.6 & 5.2 & 6.4 & 7.9 & 8.4 & 8.9 & 9.2 & 8.8 & 9.2 & 9.5 & 9.2 & 9.4 & 9.2 & 9.1 \\ 3.8 & 3.8 & 3.7 & 3.8 & 3.9 & 4.0 & 4.1 & 4.3 & 4.4 & 4.3 & 4.3 & 4.2 & 4.0 & 4.0 \\ 7.38 & 7.40 & - & 7.38 & - & 7.40 & - & 7.38 & - & 7.40 & - & 7.37 & - & 7.35 \\ & & & & & & & & & & & & & \\ 4.9 & 4.9 & 5.7 & 8.1 & 9.6 & 11.1 & 12.1 & 12.8 & 13.2 & 13.1 & 13.6 & 13.5 & 13.3 & 14.0 \\ 3.6 & 3.7 & 3.9 & 3.9 & 3.9 & 3.9 & 4.0 & 4.1 & 4.2 & 4.1 & 4.3 & 4.4 & 4.1 & 4.0 \\ 7.51 & 7.49 & - & 7.48 & - & 7.43 & - & 7.44 & - & 7.43 & - & 7.30 & - & 7.25 \\ \end{array}$




\section{Discussion}

The potassium increase which appears after insulin withdrawal may partly be due to lack of insulin activity [2]. As in normal subjects, the increment of this ion does not seem related to glucose levels. Moreover, it is not due to a fall of blood $\mathrm{pH}$ in agreement with the data of Gerich et al. [3] who in the same experimental conditions demonstrated that a significant increase in plasma ketoacids was only present many hours after insulin withdrawal. In our previous study [1], using somatostatin (which inhibits insulin, glucagon and growth hormone secretion) plus glucagon replacement, we demonstrated that the latter had a hyperkalaemic effect. In accordance with those findings, the present results indicate that glucagon inhibition by somatostatin inhibits potassium increase, indicating that the potassium increment after insulin withdrawal is possibly sustained by a rise in plasma glucagon.

It is noteworthy that in the control test without somatostatin, glucagon rose slightly to values within the normal range. This finding underlines the possible role of glucagon in the physiological control of plasma potassium levels and indicated that glucagon may be a contributory factor to the development of hyperkalaemia in decompensated diabetes [4].
Acknowledgements. We wish to thank Hoechst, Milan for the supply of cyclic somatostatin. This work was supported in part by CNR Contributo di Ricerca No. CT 80.00898.04.

\section{References}

1. Massara F, Martelli S, Cagliero E, Camanni F, Molinatti GM (1980) Influence of glucagon on plasma levels of potassium in man. Diabetologia 19: 414-417

2. DeFronzo RA, Sherwin RS, Dillingham M, Hendler R, Tamborlane WV, Felig P (1978) Influence of basal insulin and glucagon secretion on potassium and sodium metabolism. Studies with somatostatin in normal dogs and in normal and diabetic human beings. $J$ Clin Invest 61: 472-479

3. Gerich J, Lorenzi M, Bier DM, Schneider V, Tsalikian E, Karam SM, Forsham PM (1975) Prevention of human diabetic ketoacidosis by somatostatin: evidence for an essential role of glucagon. $\mathrm{N}$ Engl J Med 292: 985-989

4. DeFronzo RA, Sherwin RS, Felig P, Bia M (1977) Non-uremic diabetic hyperkalaemia. Possible role of insulin deficiency. Arch Intern Med 137: 842-843

Received: 4 August 1981 and in revised form: 6 August 1982

Dr. F. Massara

Cattedra di Endocrinologia

Corso Polonia, 14

10126 - Torino

Italy 